\title{
The changes of Th17 cells and the related cytokines in the progression of human colorectal cancers
}

\author{
Jiansheng Wang ${ }^{1,4}$, Kaiyu $\mathrm{Xu}^{1}$, Jing $\mathrm{Wu}^{1}$, Chenghua Luo ${ }^{1}$, Yuchen $\mathrm{Li}^{1}$, Xuebin $\mathrm{Wu}^{1}$, Hong Gao ${ }^{1}$, \\ Guosheng Feng ${ }^{1,3}$ and Bao-Zhu Yuan ${ }^{1,2^{*}}$
}

\begin{abstract}
Background: The role of Th17 cells in colorectal tumorigenesis and development still remains unclear, despite the fact that it has been established in the pathogenesis of autoimmune diseases.

Methods: We first analyzed Th17 cells and Treg cells using flow cytometry in the circulation of colorectal adenoma (CRA) and colorectal carcinoma (CRC) patients and healthy controls, and the frequency of Th17 cells in peripheral blood mononuclear cells (PBMCs) stimulated by anti-CD3 plus anti-CD28 and treated by IL-1 $\beta$, IL-6, and TGF- $\beta$ in different concentrations. We then detected cytokines IL-1 $\beta, I L-6, I L-17 A, I L-21, I L-23$ or TGF- $\beta$ by ELISA in sera and supernatants from both normal and tumor tissues cultured ex vivo.

Results: It was found that the percentage of Th17 and Treg cells increased in the circulation of both CRA and CRC patients; the increase of Th17 cells in the circulation occurred in early stages, whereas the increase of Treg cells in the circulation and the increase of Th17 cells in tumor tissues occurred in advanced stages. The subsequent cytokine profiling showed that, along CRC progression, IL-1 $\beta, I L-17 A$ and IL-23 underwent a similar change, while IL-6 in CRC exhibited an opposite change, with Th17 cells. In addition, high levels of TGF- $\beta$ and IL-17A were detected in tumor tissues rather than in normal mucosa. The in vitro experiment further demonstrated that IL-1 $\beta$, IL-6 or TGF- $\beta$ modulated Th17 cell expansion in PBMC.
\end{abstract}

Conclusions: Our study reveals a unique change of Th17 cells, which is regulated possibly by IL-1 $\beta$, IL-6 and TGF- $\beta$ in the progression of CRC.

Keywords: Colorectal adenoma, Colorectal cancer, Th17 cells, Treg cells, Cytokines

\section{Background}

Colorectal cancer (CRC) is one of the leading causes of cancer death in the world. Although the modality of CRC has recently showed a slow reduction due to improvement in early detection and/or treatment in the United States, it still keeps rising in China, especially in the big metropolitan areas [1,2], thus still imposing a severe threat to human health.

According to the adenoma-carcinoma sequence hypothesis [3], CRC develops through a multistep process

\footnotetext{
* Correspondence: ybao4356@gmail.com

'Department of Oncology, Beijing Shijitan Hospital, Capital Medical University, Beijing, China 100038

${ }^{2}$ Department of Cell Biology, Institute for Biological Products Control, National Institutes for Food and Drug Control, Beijing, China 100050 Full list of author information is available at the end of the article
}

from initially low-grade dysplastic adenoma to highgrade dysplastic adenoma and ultimately to carcinoma. Progression through this sequence is accompanied by accumulation of tumorigenesis-related genetic mutations and molecular changes [3,4]. The increasing evidence shows that the balance in different CD4-positive $\mathrm{T}$ lymphocyte subpopulations and cytokine networks are also deregulated [4-6]. The changes of cytokine profiles in the serum may be early events along the colorectal adenoma-carcinoma sequence. Thus, they may serve as important biological indices for the prognosis of CRC [6-8]. In addition, subtyping of immune cells within tumor tissues may be more effective in evaluating disease status than genetic changes [9-11].

Among different $\mathrm{T}$ lymphocyte subpopulations, $\mathrm{CD} 4{ }^{+} \mathrm{CD} 25^{+} \mathrm{T}$ cells (Tregs) are vital in maintaining

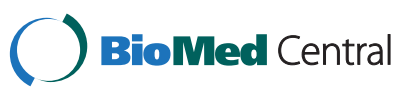


immune tolerance and homeostasis. But they may promote tumor progression by inhibiting anti-cancer immune responses $[12,13]$. Recent evidence suggests that expression of IL-7 receptor-chain (also known as CD127) on cell surface is inversely correlated with the suppressive function of $\mathrm{CD} 4{ }^{+} \mathrm{CD} 25^{\mathrm{hi}}$ Tregs and the expression of Foxp3, which is an Treg-expressing transcription factor, so the Tregs can also be characterized by $\mathrm{CD} 4^{+} \mathrm{CD} 25^{+} \mathrm{CD} 127^{\mathrm{lo} /-}$ phenotype $[14,15]$.

Recently, the Th17 cell, which is another CD4-positive $\mathrm{T}$ lymphocyte subpopulation with its designation following the feature of secreting IL-17, has been extensively described for its involvement in several autoimmune diseases and chronic inflammatory syndromes [16,17]. However, the role of Th17 cells in tumor immunity was less studied as compared with Treg cells.

Among all cytokines, IL-1 $\beta$, IL-6, IL-17, IL-21, IL-23 and TGF- $\beta$ have been implicated in several autoimmune diseases and inflammatory disorders. They are also known to be able to modulate differentiation and development of Th17 cells and Treg cells $[17,18]$. In mice, low doses of TGF- $\beta$, together with IL- 6 or IL-21 can initiate differentiation of naïve $\mathrm{CD} 4^{+} \mathrm{T}$ cells into the Th17 lineage, while high doses of TGF- $\beta$ can drive formation of the Treg lineage from naïve $\mathrm{CD} 4^{+} \mathrm{T}$ cell $[19,20]$. IL-23 is thought to be required in the maintenance of Th17 cell phenotype $[17,19,21,22]$. In humans, in addition to IL-6, IL-21, TGF- $\beta$ and IL-23,IL-1 $\beta$ was also found important in regulating Th17 cell differentiation [22-26].

Despite a great knowledge about differentiation and function of Th17 cells in both mice and humans has been accumulated, generation and regulation of Th17 cells in human cancer, especially in colorectal cancer, still remain unclear. In this study, we investigated the changes of Th17 and Treg cells, and the related cytokines in the peripheral blood of patients with colorectal adenoma (CRA) or CRC. We also detected the frequency of Th17 cells and concentrations of the related cytokines in both CRC tissues and the surrounding normal tissues. In addition, to determine which cytokines play more dominant roles in the prevalence of Th17 cells, we subsequently assessed in an in vitro experiment the effect of the related cytokines on the expansion of Th17 cells from peripheral blood mononuclear cells (PBMCs).

\section{Methods}

\section{Patients}

Sixty six patients of 35 sporadic colorectal cancers and 31 colorectal adenomas, admitted in Beijing Shijitan Hospital from June 2010 to July 2011, were enrolled in this study. Both CRA and CRC patients were divided into two groups based on disease progression. The findings of tubular I and tubular II correspond to early stage and late stage, respectively, for CRA patients; the stage I/II and stage III/IV were considered as early and late stage, respectively for CRC patients. None of them received radiotherapy, chemotherapy, or immunotherapy before sample collection. The subjects with cancer history, autoimmune diseases, infectious diseases, inflammatory bowel diseases and familial polyposis were excluded in this study. Patient profiles are summarized in Table 1. Twenty four healthy donors without history of tumor or other serious illnesses, in which 12 are female and 12 are male with mean age at 63 ranging from 42 to 83 , were included as controls. The sample collection was performed with a written informed consent for each subject and the study was conducted with the approval of the Shijitan Hospital's ethics committee and in compliance with the Helsinki Declaration.

\section{Reagents}

Collagenase type IV, hyaluronidase, deoxyribonuclease type I, Ficoll-Hypaque and Percoll were from SigmaAldrich. Recombinant IL-1 $\beta$, IL-6 and TGF- $\beta 1$ were

Table 1 Clinical features of patients with colorectal adenoma and carcinoma

\begin{tabular}{|c|c|c|}
\hline & $\begin{array}{l}\text { Colorectal } \\
\text { adenocarcinoma }\end{array}$ & $\begin{array}{l}\text { Colorectal } \\
\text { adenoma }\end{array}$ \\
\hline \multicolumn{3}{|l|}{ Sex } \\
\hline Male & 15 & 21 \\
\hline Female & 20 & 10 \\
\hline \multicolumn{3}{|l|}{ Age, y } \\
\hline Median & 64 & 67 \\
\hline Range & $43-86$ & $45-83$ \\
\hline \multicolumn{3}{|l|}{ Location } \\
\hline Right side of colon & 5 & 6 \\
\hline Transverse colon & 4 & 3 \\
\hline Left side of colon & 3 & 5 \\
\hline Sigmoid colon & 8 & 10 \\
\hline Rectum & 15 & 7 \\
\hline \multicolumn{3}{|c|}{ Adenocarcinoma differentiation } \\
\hline Well & 8 & \\
\hline Moderate & 20 & \\
\hline Poor & 7 & \\
\hline \multicolumn{3}{|l|}{ AJCC cancer stage } \\
\hline 1 & 4 & \\
\hline$\|$ & 10 & \\
\hline III & 17 & \\
\hline IV & 4 & \\
\hline \multicolumn{3}{|c|}{ Adenoma histological grade } \\
\hline Tubularl & & 19 \\
\hline Tubularll & & 12 \\
\hline
\end{tabular}


from PeproTech. Anti-human CD4, CD25 and isotype controls were from BD Bioscience. Phorbol 12-myristate 13-acetate (PMA), ionomycin, Brefeldin A, FIX \& PERM Kit Reagent, IL-1 $\beta$, IL-6, IL-17A, IL-21, IL-23, TGF- $\beta$ ELISA kit, and Anti-human CD3, CD28, CD8, CD127, IL-17A and isotype controls were from eBioscience.

\section{Tissue culture}

Tissue culture was performed as previously described [27]. Briefly, tumor tissue or normal mucosa was washed, weighed, and then placed in a small tissue culture dish containing RPMI-1640 medium supplemented with 10\% FBS and antibiotics. After incubation at $37^{\circ} \mathrm{C}$ with $5 \%$ $\mathrm{CO} 2$ for $24 \mathrm{~h}$ and then centrifugation, the supernatant of each sample was used for cytokine measurements.

\section{Cell isolations}

Normal infiltrating lymphocytes (NILs) and tumor infiltrating lymphocytes (TILs) were isolated from freshly resected surgical specimens by a method reported previously with some modifications [28]. In brief, the epithelial layer was removed by stirring in $1 \mathrm{mM}$ EDTA and $1 \mathrm{mM}$ DTT for $1 \mathrm{~h}$ at $37^{\circ} \mathrm{C}$. The tissue was minced, then treated with a digestion solution containing $0.5 \mathrm{mg} / \mathrm{ml}$ collagenase type IV, $1 \mathrm{mg} / \mathrm{ml}$ hyaluronidase and $0.1 \mathrm{mg} / \mathrm{ml}$ deoxyribonuclease type I for $2 \mathrm{~h}$ with stirring at $37^{\circ} \mathrm{C}$. After digestion, the cells were washed and centrifuged over a discontinuous Percoll gradient (75\% and $40 \%)$. PBMCs were isolated using Ficoll-Hypaque gradient. The cells at the interface were harvested, washed and resuspended in RPMI-1640 complete medium. The cell viability was determined by trypan blue exclusion.

\section{Stimulation of PBMCs}

The freshly isolated PBMCs $\left(1 \times 10^{6}\right.$ cells/well $)$ from health donors were stimulated in $4 \mu \mathrm{g} / \mathrm{ml}$ anti-CD3 monoclonal antibody-coated 96-well plate and $2 \mu \mathrm{g} / \mathrm{ml}$ anti-CD28 antibody, and incubated for $84 \mathrm{~h}$ with RPMI1640 complete medium containing different cytokines (IL-1ß, 10 and $25 \mathrm{ng} / \mathrm{ml}$; IL-6, 25 and $50 \mathrm{ng} / \mathrm{ml}$; TGF- $\beta 1$, 5 and $0.5 \mathrm{ng} / \mathrm{ml}$ ) alone or in combination. For intracellular cytokine staining, the purified PBMCs, NILs and TILs were stimulated for $5 \mathrm{~h}$ in RPMI complete medium with $50 \mathrm{ng} / \mathrm{ml}$ PMA and $1 \mu \mathrm{g} / \mathrm{ml}$ ionomycin in the presence of $10 \mu \mathrm{g} / \mathrm{ml}$ Brefeldin A.

\section{Cytokine measurements}

Concentrations of cytokines IL-1 $\beta$, IL-6, IL-17A, IL-21, IL-23 or TGF- $\beta$ in sera, supernatants of tissue, and cell cultures of the stimulated PBMCs were measured using a specific ELISA kit. Results of the cytokine concentrations in the supernatant of tissue cultures are expressed as $\mathrm{pg} / \mathrm{mg}$ of tissue weight $/ \mathrm{ml}$ of culture medium.

\section{Flow cytometry assays}

Surface protein staining of PBMCs, NILs and TILs were performed at room temperature for $20 \mathrm{~min}$ using the following antibodies: the PE-Cy5-conjugated anti-CD3 and FITC-conjugated anti-CD8 were used for staining Th17 cells; the FITC-conjugated anti-CD4 and $\mathrm{PE}-\mathrm{Cy}^{\mathrm{TM}} 7$-conjugated anti-CD25 and PE-conjugated anti-CD127 were used for Treg Cells. Before staining with the PE-conjugated anti-IL-17A, cells were washed, fixed and permeated using FIX \& PERM Kit Reagent following the manufacturer's instructions. The isotype control of each dye-conjugated antibody was used to correct compensation and confirm antibody specificity. The stained cells were analyzed by a Calibur flow cytometer equipped with CellQuest software.

\section{Statistical analysis}

Data were analyzed by SPSS statistical software (version 16, SPSS Inc., Chicago, IL) using Student's t test or one-way ANOVA and the Mann-Whitney U test or the KruskalWallis test. A level of $P<0.05$ was considered statistically significant.

\section{Results}

\section{Percentage of the circulating Th17 cells in CRA and CRC} patients

To investigate the changes of Th17 cells in the progression of CRC, we first measured Th17 cells in the PBMCs of CRA and CRC patients and healthy controls. The analysis for the percentage of Th17 cell in total $\mathrm{CD} 4^{+} \mathrm{T}$ cells in patients and controls were shown in Figure 1. The percentage of Th17 cells was significantly increased in both CRA (median, $1.2 \% ; 25^{\text {th }}$ to $75^{\text {th }}$ percentiles, $0.6 \%$ to $1.6 \% ; P=0.028)$ and CRC patients $(1.7 \% ; 1.3 \%$ to $2.4 \% ; P<0.001)$ as compared with healthy controls (0.7\%; $0.4 \%$ to $1.2 \%)$. In addition, the percentage of Th17 cells in CRC patients was significantly higher than that in CRA patients $(P=0.001)$. Following disease progression, we observed that the percentage of Th17 cells was decreased in advanced stages of both CRAs and CRCs in comparison with early stage of each disease $(0.8 \% ; 0.5 \%$ to $1.3 \%$ vs $1.4 \% ; 0.6 \%$ to $2.0 \%, P=0.014 ; 1.4 \% ; 1.3 \%$ to $1.9 \%$ vs $2.2 \% ; 1.6 \%$ to $3.8 \%, P=0.025)$. Although both in advanced stages, CRC patients showed a higher percentage of Th17 cells than CRA patients $(P=0.002)$.

\section{Distribution of Th17 cells in NILs and TILs}

Subsequently, we found that percentage of Th17 cells in TILs $(1.8 \% ; 0.8 \%$ to $2.8 \%)$ was increased as compared with NILs $(1.7 \%$; $0.8 \%$ to $2.6 \%)$ or PBMCs $(1.6 \% ; 1.2 \%$ to $2.5 \%)$, but did not show any statistical significance. However, the percentage of Th17 cells in the TILs of patients in advanced stages was significantly higher than that in 


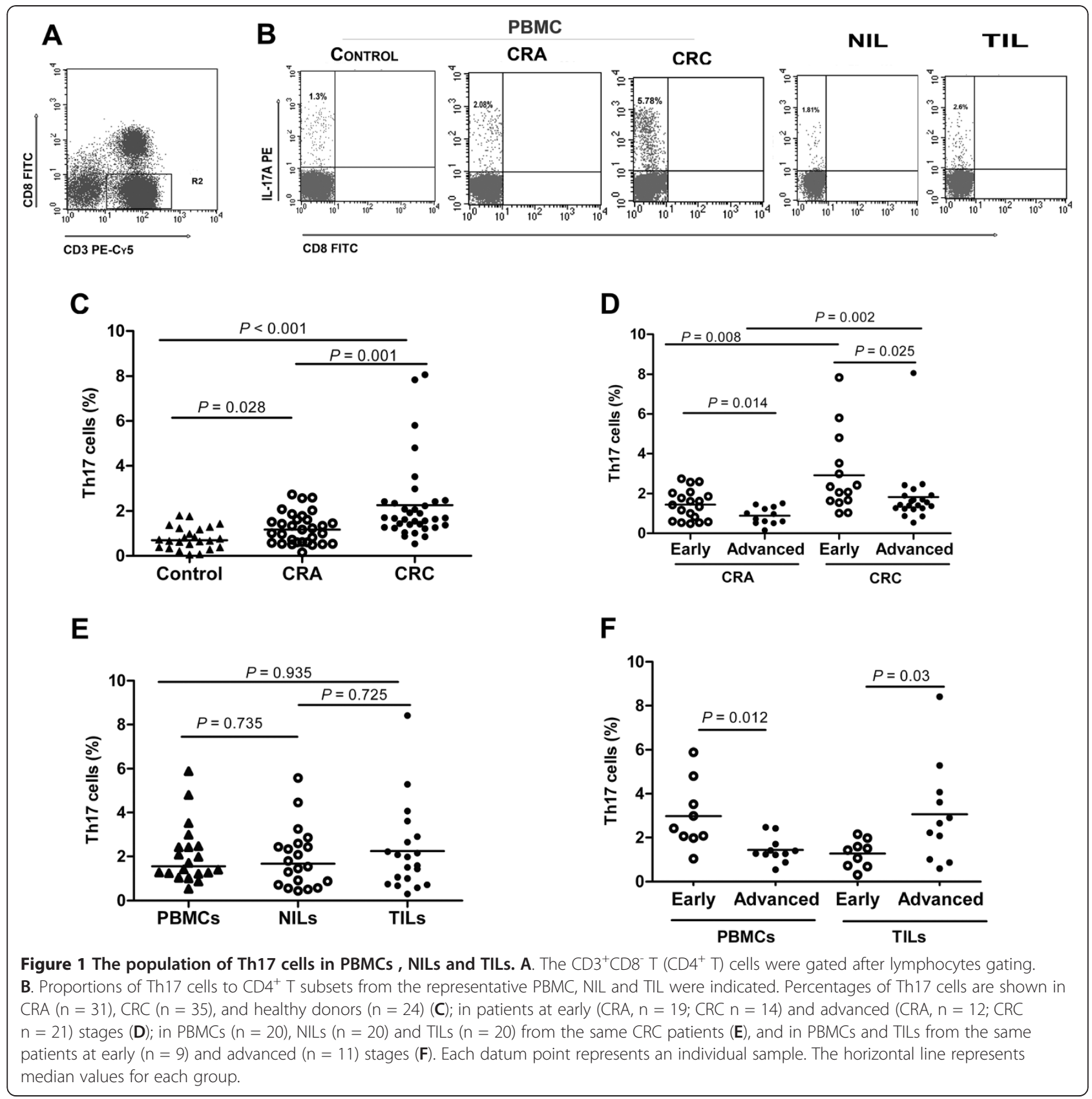

early stages $(2.7 \% ; 1.0 \%$ to $4.1 \%$ vs $1.4 \% ; 0.7 \%$ to $1.8 \%$, $P=0.03$ ) (Figure 1).

\section{Percentage of the circulating Tregs in CRA and CRC patients}

Observations of Tregs in this study showed that percentage of Tregs was significantly increased in CRA and CRC patients $(3.6 \% ; 3.0 \%$ to $5.3 \%, P=0.002 ; 4.4 \% ; 2.6 \%$ to $5.9 \%, P=0.002)$ as compared with healthy controls (2.8\%; $2.2 \%$ to $3.6 \%)$. Although the percentage of Tregs was higher in CRC patients than that in CRA patients, no significant difference was observed between them
$(P=0.36)$. In contrast to Th17 cells, the percentages of circulating Tregs were significantly higher in advanced stages than in early stages of both CRA and CRC patients $(4.4 \% ; 3.4 \%$ to $6.0 \%$ vs $3.5 \% ; 2.5 \%$ to $4.7 \%, P=$ $0.047 ; 5.4 \% ; 4.1 \%$ to $7.0 \%$ vs $2.5 \% ; 1.2 \%$ to $3.8 \%, P=$ 0.003) (Figure 2).

Seral concentrations of IL-1 $\beta$, IL-6, IL-17A and IL-23 of CRA and CRC patients

To investigate whether the changes of Th17 cells were accompanied by cytokine alterations, we then measured seral concentrations of IL-1 $\beta$, IL-6, IL-17A and IL-23 in 
A
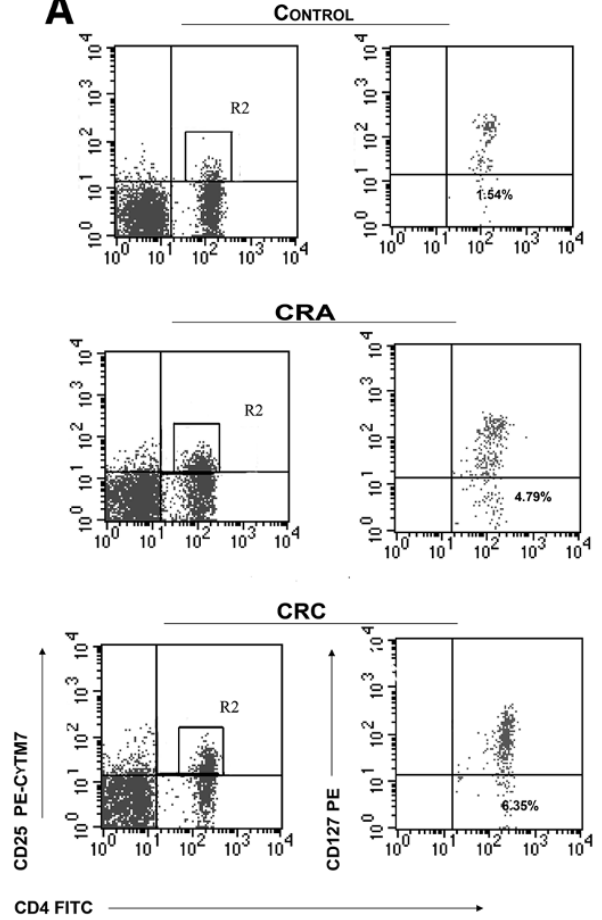

B

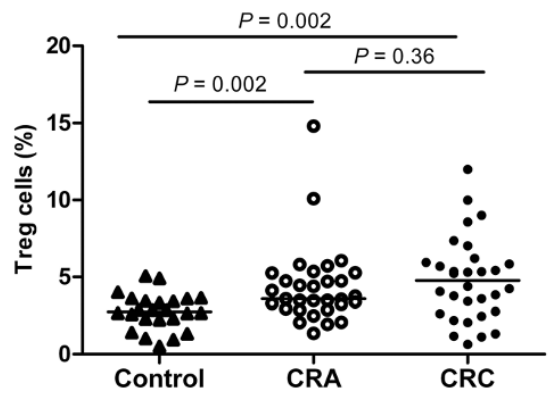

C

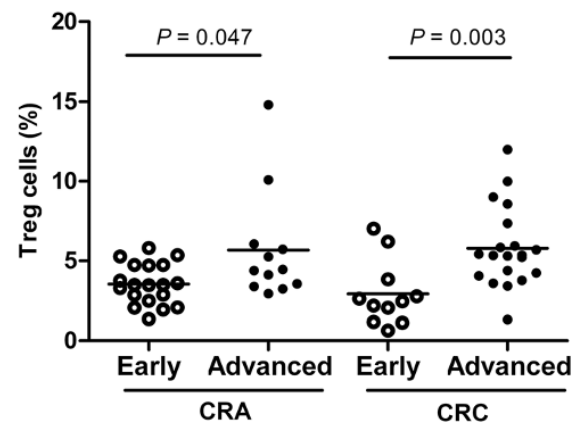

Figure 2 Population of the Treg cells in PBMCs. A. $C D 4^{+} \mathrm{CD} 25^{+} \mathrm{T}$ cells were gated after lymphocytes gating and the calculated numbers of $\mathrm{CD} 4^{+} \mathrm{CD} 25^{+} \mathrm{CD} 127^{-} \mathrm{T}$ cells in $\mathrm{CD} 4^{+} \mathrm{T}$ cells were indicated in the representative control, CRA and CRC patient. Percentages of Treg cells are shown in CRA $(n=31), C R C(n=31)$, and healthy controls $(n=24)(B)$, and in patients at early $(C R A, n=19 ; C R C n=11)$ and advanced $(C R A, n=12$; $C R C n=20)$ stages $(\mathbf{C})$. Each datum point represents an individual sample. The horizontal line represents median values for each group.

patients with CRA and CRC and healthy donors. As shown in Figure 3, concentrations of IL-17A and IL-23 were higher in CRA patients (IL-17A: $6.4 \pm 0.8 \mathrm{pg} / \mathrm{ml}$, $P=0.242$; IL-23: $34.6 \pm 4.4 \mathrm{pg} / \mathrm{ml}, P=0.004)$ and highest in CRC patients $(16.1 \pm 2.5 \mathrm{pg} / \mathrm{ml}, P<0.001$; $55.2 \pm 5.5 \mathrm{pg} / \mathrm{ml}, P<0.001)$ as compared with healthy controls $(5.0 \pm 0.8 \mathrm{pg} / \mathrm{ml} ; 18.6 \pm 2.7 \mathrm{pg} / \mathrm{ml})$. However, IL-1 $\beta$ and IL-6 were higher in CRC (IL-1 $\beta$ : $7.3 \pm$ $0.6 \mathrm{pg} / \mathrm{ml}, P<0.001$; IL-6: $25.6 \pm 2.6 \mathrm{pg} / \mathrm{ml}, P=0.001$ ) but highest in CRA $(9.3 \pm 0.6 \mathrm{pg} / \mathrm{ml}, P<0.001 ; 33.9 \pm$ $2.1 \mathrm{pg} / \mathrm{ml}, P<0.001$ ) as compared with healthy controls $(4.6 \pm 0.2 \mathrm{pg} / \mathrm{ml} ; 11.2 \pm 2.3 \mathrm{pg} / \mathrm{ml})$. Following disease progression, we further found that IL-1 $\beta$, IL-17A and IL-23 were significantly higher in early stages than in advanced stages of CRA patients (IL-1 $\beta: 11.4 \pm 0.6 \mathrm{pg} / \mathrm{ml}$ vs $6.2 \pm 0.4 \mathrm{pg} / \mathrm{ml}, P<0.001$; IL- $17 \mathrm{~A}: 7.6 \pm 1.2 \mathrm{pg} / \mathrm{ml}$ vs $4.7 \pm 0.5 \mathrm{pg} / \mathrm{ml}, P=0.038$; IL-23: $42.8 \pm 6.5 \mathrm{pg} / \mathrm{ml}$ vs $22.2 \pm 3.1 \mathrm{pg} / \mathrm{ml}, P=0.015)$ and CRC patients $(9.3 \pm$ $1.2 \mathrm{pg} / \mathrm{ml}$ vs $6.0 \pm 0.5 \mathrm{pg} / \mathrm{ml}, P=0.022 ; 25.1 \pm 3.7 \mathrm{pg} / \mathrm{ml}$ vs $10.2 \pm 2.8 \mathrm{pg} / \mathrm{ml}, P=0.002 ; 68.4 \pm 9.5 \mathrm{pg} / \mathrm{ml}$ vs $46.5 \pm$ $6.2 \mathrm{pg} / \mathrm{ml}, P=0.043)$. Regardless of disease stages, IL17A and IL-23 exhibited higher levels in CRC patients than in CRA patients (IL-17A: $P<0.001$ or $P=0.068$; IL-23: $P=0.029$ or $P=0.002$ ), whereas IL- 6 concentration was increased in the advanced CRCs (28.3 \pm $3.3 \mathrm{pg} / \mathrm{ml}$ vs $21.7 \pm 2.6 \mathrm{pg} / \mathrm{ml}, P=0.154$ ) but decreased in the advanced CRAs $(27.7 \pm 3.1 \mathrm{pg} / \mathrm{ml}$ vs $38.0 \pm$ $2.4 \mathrm{pg} / \mathrm{ml}, P=0.013$ ) as compared with early stage of each disease.

Concentrations of IL-1 $\beta$, IL-6, IL-17A, IL-21, IL-23 and TGF- $\beta$ released from the cultured tissues

To reveal cytokine changes in tissues, we then measured concentrations of IL-1 $\beta$, IL-6, IL-17A, IL-21, IL-23 and TGF- $\beta$ in the supernatants of the cultured normal colorectal mucosa and CRC tissues. As shown in Figure 4, in comparison with normal mucosa, the tumor tissues released significantly higher amounts of IL-17A (224.2 \pm $34.2 \mathrm{pg} / \mathrm{mg}$ tissue vs $148.3 \pm 14.0 \mathrm{pg} / \mathrm{mg}$ tissue, $P=$ $0.047)$ and TGF- $\beta(1311.5 \pm 157.6 \mathrm{pg} / \mathrm{mg}$ tissue vs $649.5 \pm$ $75.6 \mathrm{pg} / \mathrm{mg}$ tissue, $P=0.001)$, but not IL-1 $\beta(P=0.144)$, IL-21 $(P=0.262)$, IL-23 $(P=0.489)$ and IL-6 $(P=0.513)$. However, we found that the tissues of the advanced CRC released significantly higher amount of IL-1 $\beta$ (2305.8 \pm $618.8 \mathrm{pg} / \mathrm{mg}$ tissue vs $822.2 \pm 240.9 \mathrm{pg} / \mathrm{mg}$ tissue, $P=$ 0.044) than the tissues of the early CRC, while the release of IL-6 $(4365.9 \pm 317.1 \mathrm{pg} / \mathrm{mg}$ tissue vs $3026.2 \pm$ $506.3 \mathrm{pg} / \mathrm{mg}$ tissue, $P=0.048$ ) was significantly higher from the early CRCs than from the advanced CRCs. But IL-17A, IL-23, IL-21 and TGF- $\beta$ released from the CRC tissues did not show a significant stage-associated change. 


\section{A}

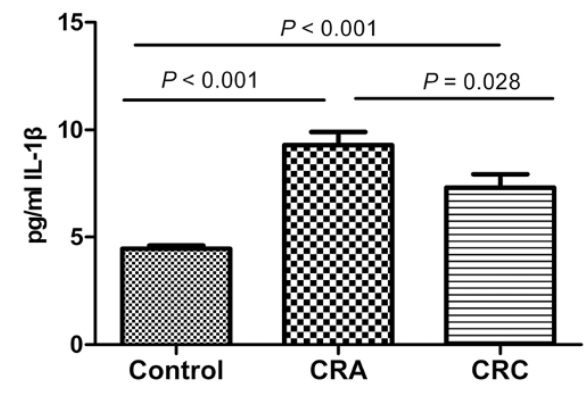

B
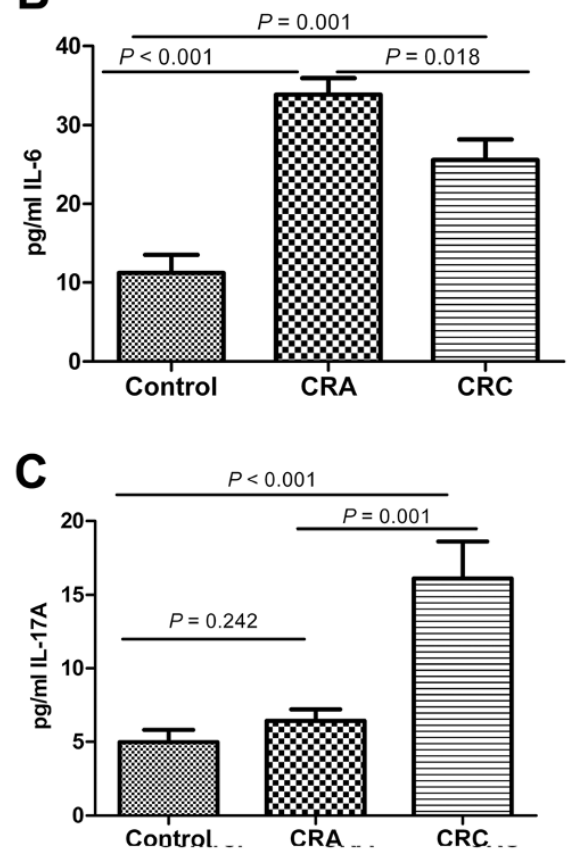

D

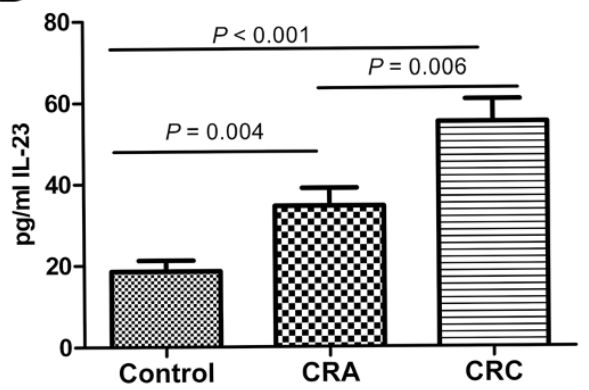

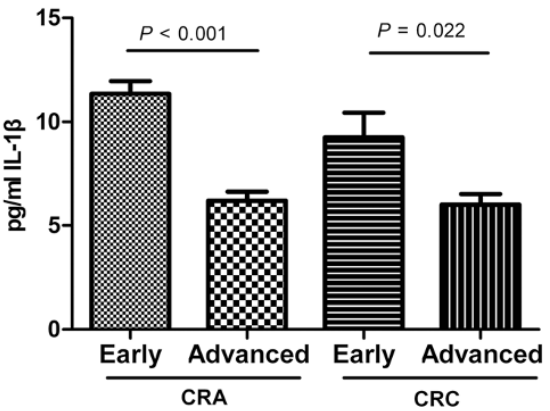
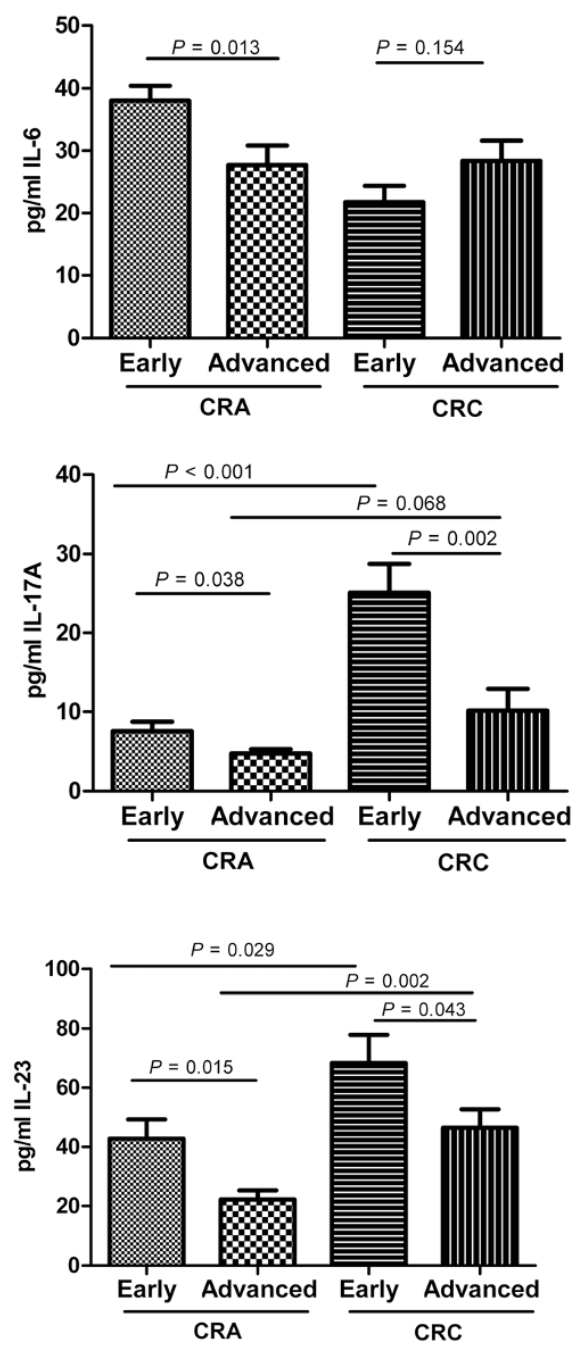

Figure 3 Cytokine measurement in serum. Concentrations of IL-1 $\beta(\mathbf{A}), \mathrm{IL}-6(\mathbf{B}), \mathrm{IL}-17 \mathrm{~A}(\mathbf{C})$ and IL-23 (D) in the serum of health donors $(\mathrm{n}=16)$ and patients with CRA ( $n=30$; early stage, $n=18$; advanced stage, $n=12)$ and CRC ( $n=35$; early stage, $n=14$; advanced stage, $n=21)$ were measured by ELISA. The cytokine concentration $(\mathrm{pg} / \mathrm{ml})$ is expressed as mean $\pm \mathrm{SEM}$.

Effect of IL-1 $\beta$, IL- 6 and TGF- $\beta$ on the expansion of Th17 cells in PBMCs

To further determine whether the changes of Th17 cells were the consequence of the alteration of IL-1 $\beta$, IL-6 and TGF- $\beta$, we investigated the effects of IL-1 $\beta$, IL-6 and TGF- $\beta$ on the expansion of Th17 cells in PBMCs. The medium from PBMCs stimulated by anti-CD3 plus anti-CD28 with no cytokine treatment served as a 
A

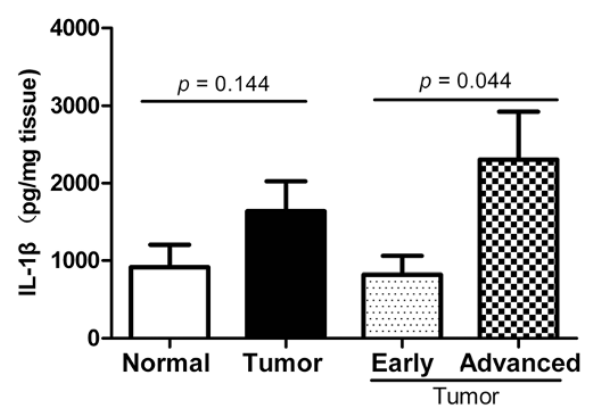

C

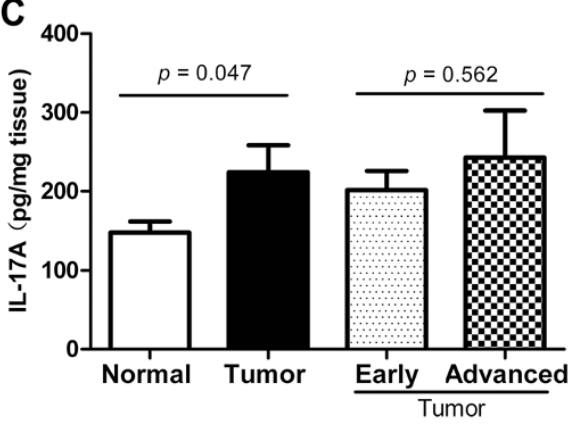

E

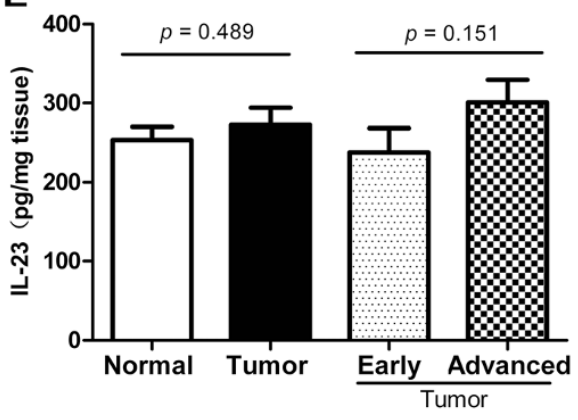

B

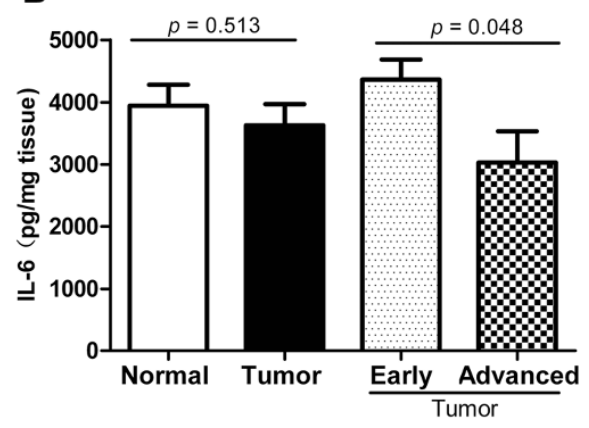

D

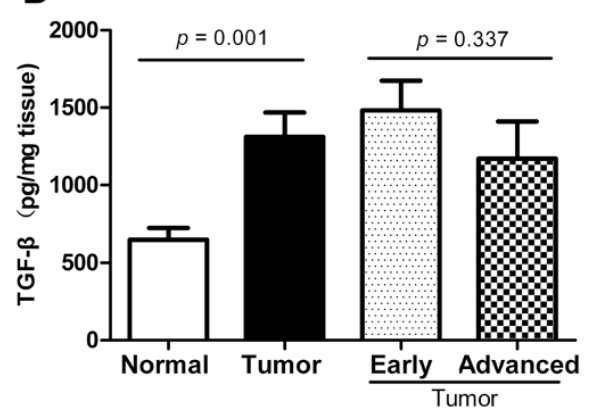

$\mathbf{F}$

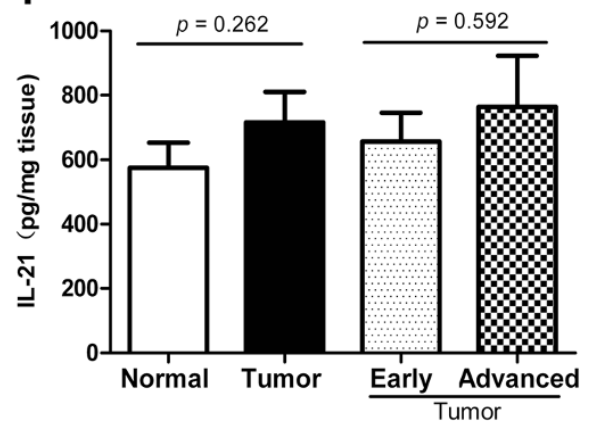

Figure 4 Cytokine measurement in the supernatants of tissue culture. Concentrations of IL-1 $\beta$ (A),IL-6 (B),IL-17A (C), TGF- $\beta$ (D), IL-23 (E),IL-21 $(\mathbf{F})$ in the supernatant of colorectal normal tissues $(n=20)$ and $C R C$ tissues $(n=20$; early stage, $n=9$; advanced stage, $n=11)$ of the same $C R C$ patients were measured by ELISA. The cytokine concentration ( $\mathrm{pg} / \mathrm{mg}$ tissue) is expressed as mean $\pm \mathrm{SEM}$.

control. Results in Figure 5 showed that $50 \mathrm{ng} / \mathrm{ml} \mathrm{IL-6}$ or $5 \mathrm{ng} / \mathrm{ml}$ TGF- $\beta$ alone reduced the number of Th17 cells in comparison with $25 \mathrm{ng} / \mathrm{ml} \mathrm{IL-6}(P=0.037)$ or $0.5 \mathrm{ng} / \mathrm{ml}$ TGF- $\beta(0.5 \mathrm{ng} / \mathrm{ml})(P=0.038)$ alone. However, the combination of IL- $6^{\text {hi }}(50 \mathrm{ng} / \mathrm{ml})$ plus TGF- $\beta^{\text {hi }}$ $(5 \mathrm{ng} / \mathrm{ml}$ ) significantly increased Th17 cell numbers as compared with IL-6 ${ }^{\text {hi }}$ alone $(P<0.001)$. The high (hi) or low (lo) concentration of each cytokine was arbitrarily defined based on the significant effect of each cytokine on Th17 cell expansion. IL-1 $\beta^{\text {hi }}(25 \mathrm{ng} / \mathrm{ml})$ increased the number of Th17 cells as compared with no cytokine control $(P=0.037)$ or $\mathrm{IL}-1 \beta^{\text {lo }}(10 \mathrm{ng} / \mathrm{ml})(P=0.037)$, but IL- $1 \beta^{\text {hi }}$ plus TGF- $\beta^{\text {hi }}$ slightly decreased the number of Th17 cells as compared with IL- $1 \beta^{\text {hi }}(P=0.522)$. In addition, the changes of IL-17A level in the supernatants showed a similar trend with the changes of Th17 cell number, but did not show any statistical significance among different cytokine groups (data not shown).

\section{Discussion}

The present study provided for the first time comprehensive data on the changes of Th17/Treg cells and cytokines IL-1 $\beta, I L-6, I L-17 A, I L-21, I L-23$ and TGF- $\beta$ in the development and progression of CRC. It demonstrated in both CRA and CRC patients an increase of circulating Th17 cells in early stages and an increase of circulating Treg cells in advanced stages, and an increase of tumor infiltrating Th17 cells in advanced CRC tissues. The changes of Th17 cells along disease progression were accompanied by alterations of IL-1 $\beta$, IL-6, IL-17A, 


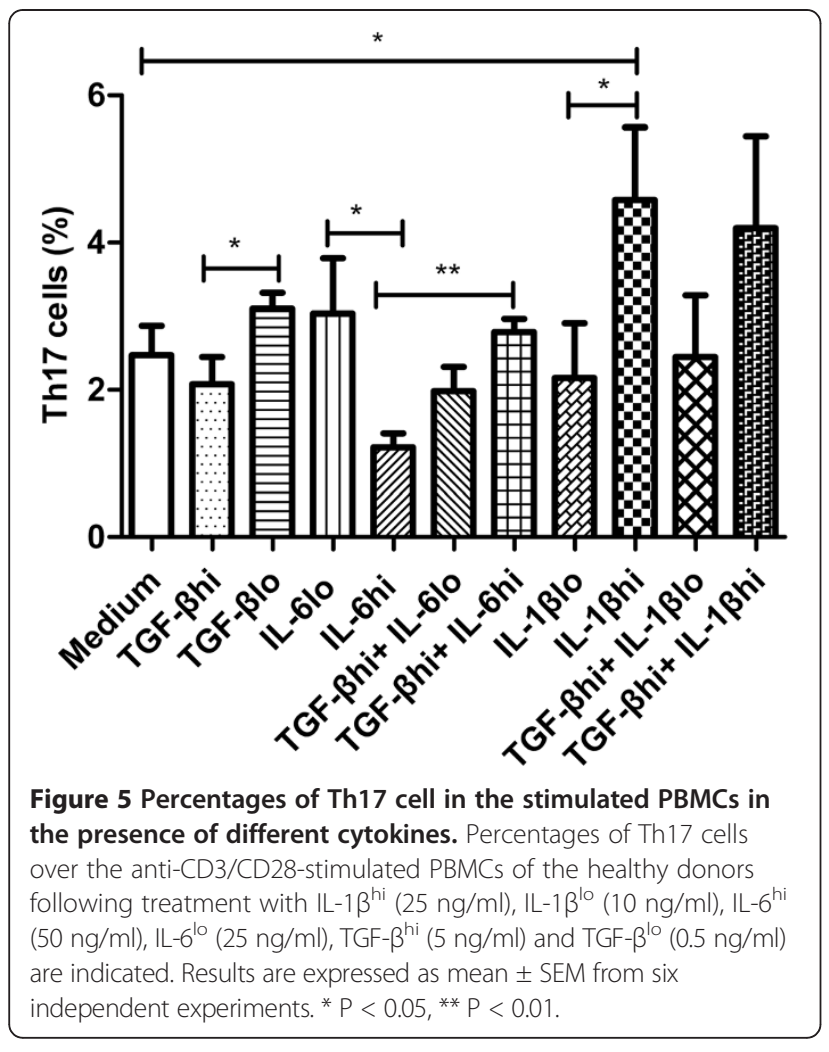

IL-23 in serum and IL-1 $\beta$, IL-6 in tumor tissues. In vitro studies further supported that the expansion of the Th17 cells were regulated by IL- $1 \beta$, IL- 6 and TGF- $\beta$ in different combinations and/or concentrations.

Previously, the elevated percentage of Th17 cells were detected in blood, bone marrow, and spleen in mouse tumor models, and in peripheral blood, malignant ascites and tumor tissues in patients of advanced ovarian, pancreatic, renal cell carcinomas, melanoma, and breast and colon cancers $[29,30]$. In gastric cancer, there were elevations of Th17 cells in the peripheral blood as well as tumor-draining lymph nodes, both of which were associated with clinical stages of cancer development [31]. However, in ovarian cancer patients, the percentage of Th17 cells appeared higher in tumor but lower in peripheral blood or PBMCs and tumor-draining lymph nodes [32,33]. Our data showed that the frequency of Th17 cells was markedly increased in the circulation of both CRA and CRC patients, but became significantly lower as the diseases progressed to the advanced stages. Moreover, our observations were consistent with an animal study, in which the Th17 cells were increased in tumor tissues as disease progressed and reached to a maximal level in advanced tumors [29].

A previous study showed that IL-1 $\beta$, IL- 6 and TGF- $\beta$ were involved in differentiation and expansion of the Th17 cells in ovarian cancers; IL- $1 \beta$ and IL- 6 promoted, whereas TGF- $\beta$ inhibited, Th17 cell expansion [32]. Our results showed that the changes in Th17 cell number along disease progression were accompanied by variations of IL-1 $\beta$, IL- 6 and IL-23 levels, suggesting the association of these cytokines with Th17 cell expansion. Given that the variation of cytokine levels, as seen in TGF- $\beta$, did not consistently follow the change of Th17 cells, we speculated the existence of an optimal level of these cytokines in regulating Th17 cell expansion. Indeed, we found that TGF- $\beta^{\text {lo }}$, IL- $6{ }^{\text {lo }}$ or IL- $1 \beta^{\text {hi }}$ increased Th17 cell number in PBMCs. However,IL- $6^{\text {hi }}$ plus TGF$\beta^{\text {hi }}$ unexpectedly promoted Th17 cell expansion, suggesting that a complex cytokine context, rather than the change of individual cytokines, is more likely involved in regulating Th17 cells. In the early stages, accumulation of Th17 cells in tumor tissues may be supported by high concentrations of TGF- $\beta$ and IL- 6 . However, following tumor progression, high level of IL-1 $\beta$, and possibly IL23 as well, with the reduced levels of IL- 6 and TGF- $\beta$ may become supporting cytokine milieu for the expansion of Th17 cells in tumor tissues.

In this study, we detected the reduced level of IL-1 $\beta$ and increased frequency of Th17 cells in the circulation of CRCs as compared with that of CRAs. Since the IL23 level is commonly elevated in the circulation of CRC patients, we speculated that IL-23 or other unknown factors, rather than IL- $1 \beta$, may be more responsible for the expansion of Th17 cells in the circulation of CRC patients. Nevertheless, new studies are needed to test this hypothesis.

Previous reports showed that IL-21 promoted differentiation of human naive $\mathrm{CD} 4^{+} \mathrm{T}$ cells into Th17 cells [23]. IL-21 was found essential in patients of inflammatory bowel diseases (IBD) in promoting IL-17 production in anti-CD3/CD28-stimulated LPMCs, whereas IL-1 $\beta$, IL-6, IL-23 and TGF- $\beta$ exerted no effects [34]. However, our observation showed no significant difference in IL-21 level between normal tissues and tumor tissues or between early and advanced CRC tissues. This discrepancy may be interpreted by the difference in immunological mechanisms for regulating Th17 cells between IBD and cancer.

Previous studies showed that Th17 cells can be recruited into tumor microenvironment from the circulation [30]. These findings are supportive at least in part to our observations that, in advanced CRCs, the Th17 cells became reduced in the circulation but increased in tumor tissues. We cannot of course exclude another possibility that the Th17 cells were converted into Treg cells during tumor progression. The emerging evidence suggested that Th17 cells are of functional plasticity and can be converted into Treg cells in vitro and these cells cannot change back to Th17 cells even under the highly favorable conditions [35,36]. Nevertheless, new studies to test these two possibilities are warranted. 


\section{Conclusions}

Our study uncovers a unique change of Th17 cells and Treg cells and cytokines IL-1 $\beta$, IL-6, IL-17A, and IL-23 along the progression of CRC. It further reveals that the Th17 cells are subjected to a complicated modulation by IL-1 $\beta, I L-6$ and TGF- $\beta$. Clearly, the current study advances our understanding of the immunological mechanisms for CRC progression. It may thus help identify novel prognostic and therapeutic strategies for this disease.

\section{Abbreviations}

CRA: Colorectal adenoma; CRC: Colorectal carcinoma; PBMCs: Peripheral blood mononuclear cells; NILs: Normal infiltrating lymphocytes; TILs: Tumor infiltrating lymphocytes; Treg: Regulatory T cell.

\section{Competing interests}

The authors declare that they have no competing interests.

\section{Authors' contributions}

WJS and YBZ have made substantial contributions to the conception and design of the study, the acquisition, analysis and interpretation of data, and been responsible for critically drafting and revising the manuscript for all critical intellectual content. YBZ has supervised the entire study and given the final approval of the revision to be published. XKY, WJ, LCH, LYC, WXB, GH, FGS have made substantial contributions to sample collections, and data acquisition and interpretation. All authors read and approved the final manuscript.

\section{Acknowledgements}

This work was supported by PI's starting fund from Shijitan Hospital and Chinese National Science and Technology Fund (H1609-81172102). The authors thank Hongbo Yu for the assistance in statistical analysis.

\section{Author details}

'Department of Oncology, Beijing Shijitan Hospital, Capital Medical University, Beijing, China 100038. ${ }^{2}$ Department of Cell Biology, Institute for Biological Products Control, National Institutes for Food and Drug Control, Beijing, China 100050. ${ }^{3}$ Beijing Chao-Yang Hospital, Capital Medical University, Beijing, China 100020. ${ }^{4}$ Present address: Clinical Laboratory, Hebe General Hospital, Shijiazhuang, Hebei, China 050051.

Received: 8 May 2012 Accepted: 31 August 2012

Published: 21 September 2012

\section{References}

1. Center MM, Jemal A, Ward E: International trends in colorectal cancer incidence rates. Cancer Epidemiol Biomarkers Prev 2009, 18:1688-1694.

2. Sung JJ, Lau JY, Young GP, Sano Y, Chiu HM, Byeon JS, Yeoh KG, Goh KL, Sollano J, Rerknimitr R, Matsuda T, Wu KC, Ng S, Leung SY, Makharia G, Chong VH, Ho KY, Brooks D, Lieberman DA, Chan FK: Asia Pacific Working Group on Colorectal Cancer: Asia Pacific consensus recommendations for colorectal cancer screening. Gut 2008, 57:1166-1176.

3. Leslie A, Carey FA, Pratt NR, Steele RJ: The colorectal adenoma-carcinoma sequence. Br J Surg 2002, 89:845-860.

4. Contasta I, Pellegrini P, Berghella AM, Del Beato T, Adorno D: Colon cancer and gene alterations: their immunological implications and suggestions for prognostic indices and improvements in biotherapy. Cancer Biother Radiopharm 2006, 21:488-505.

5. Cui G, Goll R, Olsen T, Steigen SE, Husebekk A, Vonen B, Florholmen J: Reduced expression of microenvironmental Th1 cytokines accompanies adenomas-carcinomas sequence of colorectum. Cancer Immunol Immunother 2007, 56:985-995.

6. Berghella AM, Contasta I, Pellegrini P, Del Beato T, Adorno D: Are immunological mechanisms involved in colon cancer and are they possible markers for biotherapy improvement? Cancer Biother Radiopharm 2006, 21:468-487.
7. Pellegrini P, Berghella AM, Contasta I, Del Beato T, Adorno D: The study of a patient's immune system may prove to be a useful noninvasive tool for stage classification in colon cancer. Cancer Biother Radiopharm 2006, 21:443-467.

8. Cui G, Florholmen J: Polarization of cytokine profile from Th1 into Th2 along colorectal adenoma-carcinoma sequence: implications for the biotherapeutic target? Inflamm Allergy Drug Targets 2008, 7:94-97.

9. Galon J, Costes A, Sanchez-Cabo F, Kirilovsky A, Mlecnik B, Lagorce-Pagès C, Tosolini M, Camus M, Berger A, Wind P, Zinzindohoué F, Bruneval P, Cugnenc $\mathrm{PH}$, Trajanoski Z, Fridman WH, Pagès F: Type, density, and location of immune cells within human colorectal tumors predict clinical outcome. Science 2006, 313:1960-1964.

10. Pagès F, Berger A, Camus M, Sanchez-Cabo F, Costes A, Molidor R, Mlecnik B, Kirilovsky A, Nilsson M, Damotte D, Meatchi T, Bruneval P, Cugnenc PH, Trajanoski Z, Fridman WH, Galon J: Effector memory T cells, early metastasis, and survival in colorectal cancer. N Engl J Med 2005, 353:2654-2666.

11. Ogino S, Nosho K, Irahara N, Meyerhardt JA, Baba Y, Shima K, Glickman JN, Ferrone CR, Mino-Kenudson M, Tanaka N, Dranoff G, Giovannucci EL, Fuchs CS: Lymphocytic reaction to colorectal cancer is associated with longer survival, independent of lymph node count, microsatellite instability, and CpG island methylator phenotype. Clin Cancer Res 2009, 15:6412-6420.

12. Zou W: Regulatory T cells, tumour immunity and immunotherapy. Nat Rev Immunol 2006, 6:295-307.

13. Gallimore AM, Simon AK: Positive and negative influences of regulatory T cells on tumour immunity. Oncogene 2008, 27:5886-5893.

14. Liu W, Putnam AL, Xu-Yu Z, Szot GL, Lee MR, Zhu S, Gottlieb PA, Kapranov P, Gingeras TR, FazekasdeStGroth B, Clayberger C, Soper DM, Ziegler SF, Bluestone JA: CD127 expression inversely correlates with FoxP3 and suppressive function of human CD4+ T reg cells. J Exp Med 2006, 203:1701-1711.

15. Shen LS, Wang J, Shen DF, Yuan XL, Dong P, Li MX, Xue J, Zhang FM, Ge HL, Xu D: CD4(+)CD25(+)CD127(low/-) regulatory T cells express Foxp3 and suppress effector $T$ cell proliferation and contribute to gastric cancers progression. Clin Immunol 2009, 131:109-118.

16. Tesmer LA, Lundy SK, Sarkar S, Fox DA: Th17 cells in human disease. Immunol Rev 2008, 223:87-113.

17. Miossec P, Korn T, Kuchroo VK: Interleukin-17 and type 17 helper T cells. N Engl J Med 2009, 361:888-898.

18. Leung S, Liu X, Fang L, Chen X, Guo T, Zhang J: The cytokine milieu in the interplay of pathogenic Th1/Th17 cells and regulatory $T$ cells in autoimmune disease. Cell Mol Immunol 2010, 7:182-189.

19. Bettelli E, Carrier Y, Gao W, Korn T, Strom TB, Oukka M, Weiner HL, Kuchroo VK: Reciprocal developmental pathways for the generation of pathogenic effector TH17 and regulatory T cells. Nature 2006, 441:235-238.

20. Zhou L, Lopes JE, Chong MM, Ivanov II, Min R, Victora GD, Shen Y, Du J, Rubtsov YP, Rudensky AY, Ziegler SF, Littman DR: TGF-beta-induced Foxp3 inhibits $\mathrm{T}(\mathrm{H}) 17$ cell differentiation by antagonizing RORgammat function. Nature 2008, 453:236-240.

21. Stritesky GL, Yeh N, Kaplan MH: IL-23 promotes maintenance but not commitment to the Th17 lineage. J Immunol 2008, 181:5948-5955

22. Mills $\mathrm{KH}$ : Induction, function and regulation of IL-17-producing T cells. Eur J Immunol 2008, 38:2636-2649.

23. Yang $L$, Anderson DE, Baecher-Allan C, Hastings WD, Bettelli E, Oukka M, Kuchroo VK, Hafler DA: IL-21 and TGF-beta are required for differentiation of human $\mathrm{T}(\mathrm{H}) 17$ cells. Nature 2008, 454:350-352.

24. Volpe E, Servant N, Zollinger R, Bogiatzi SI, Hupé P, Barillot E, Soumelis V: A critical function for transforming growth factor-beta, interleukin 23 and proinflammatory cytokines in driving and modulating human $\mathrm{T}(\mathrm{H})-17$ responses. Nat Immunol 2008, 9:650-657.

25. Acosta-Rodriguez EV, Napolitani G, Lanzavecchia A, Sallusto F: Interleukin 1 beta and 6 but not transforming growth factor-beta are essential for the differentiation of interleukin 17-producing human T helper cells. Nat Immunol 2007, 8:942-949.

26. Manel N, Unutmaz D, Littman DR: The differentiation of human $\mathrm{T}(\mathrm{H})-17$ cells requires transforming growth factor-beta and induction of the nuclear receptor RORgammat. Nat Immunol 2008, 9:641-649.

27. Reimund JM, Wittersheim C, Dumont S, Muller CD, Kenney JS, Baumann R, Poindron P, Duclos B: Increased production of tumour necrosis factor-alpha interleukin- 1 beta, and interleukin- 6 by morphologically 
normal intestinal biopsies from patients with Crohn's disease. Gut 1996, 39:684-689.

28. Shanahan F, Brogan M, Targan S: Human mucosal cytotoxic effector cells. Gastroenterology 1987, 92:1951-1957.

29. Kryczek I, Wei S, Zou L, Altuwaiji S, Szeliga W, Kolls J, Chang A, Zou W: Cutting edge: Th17 and regulatory $\mathrm{T}$ cell dynamics and the regulation by IL-2 in the tumor microenvironment. I Immuno/ 2007, 178:6730-6733.

30. Su X, Ye J, Hsueh EC, Zhang Y, Hoft DF, Peng G: Tumor microenvironments direct the recruitment and expansion of human Th17 cells. J Immunol 2010, 184:1630-1641.

31. Zhang B, Rong G, Wei H, Zhang M, Bi J, Ma L, Xue X, Wei G, Liu X, Fang G: The prevalence of Th17 cells in patients with gastric cancer. Biochem Biophys Res Commun 2008, 374:533-537.

32. Miyahara Y, Odunsi K, Chen W, Peng G, Matsuzaki J, Wang RF: Generation and regulation of human $\mathrm{CD}^{+} \mathrm{IL}-17$-producing $\mathrm{T}$ cells in ovarian cancer. Proc Natl Acad Sci U S A 2008, 105:15505-15510.

33. Kryczek I, Banerjee M, Cheng P, Vatan L, Szeliga W, Wei S, Huang E, Finlayson E, Simeone D, Welling TH, Chang A, Coukos G: Phenotype, distribution, generation, and functional and clinical relevance of Th17 cells in the human tumor environments. Blood 2009, 114:1141-1149.

34. Rovedatti L, Kudo T, Biancheri P, Sarra M, Knowles CH, Rampton DS, Corazza GR, Monteleone G, Di Sabatino A, Macdonald TT: Differential regulation of interleukin 17 and interferon gamma production in inflammatory bowel disease. Gut 2009, 58:1629-1636.

35. Ye J, Su X, Hsueh EC, Zhang Y, Koenig JM, Hoft DF, Peng G: Human tumor-infiltrating Th17 cells have the capacity to differentiate into IFN- $\gamma+$ and FOXP3 + T cells with potent suppressive function. Eur J Immunol 2011, 41:936-951.

36. Hoechst B, Gamrekelashvili J, Manns MP, Greten TF, Korangy F: Plasticity of human Th17 cells and iTregs is orchestrated by different subsets of myeloid cells. Blood 2011, 117:6532-6541.

doi:10.1186/1471-2407-12-418

Cite this article as: Wang et al:: The changes of Th17 cells and the related cytokines in the progression of human colorectal cancers. BMC Cancer 2012 12:418.

\section{Submit your next manuscript to BioMed Central and take full advantage of:}

- Convenient online submission

- Thorough peer review

- No space constraints or color figure charges

- Immediate publication on acceptance

- Inclusion in PubMed, CAS, Scopus and Google Scholar

- Research which is freely available for redistribution 